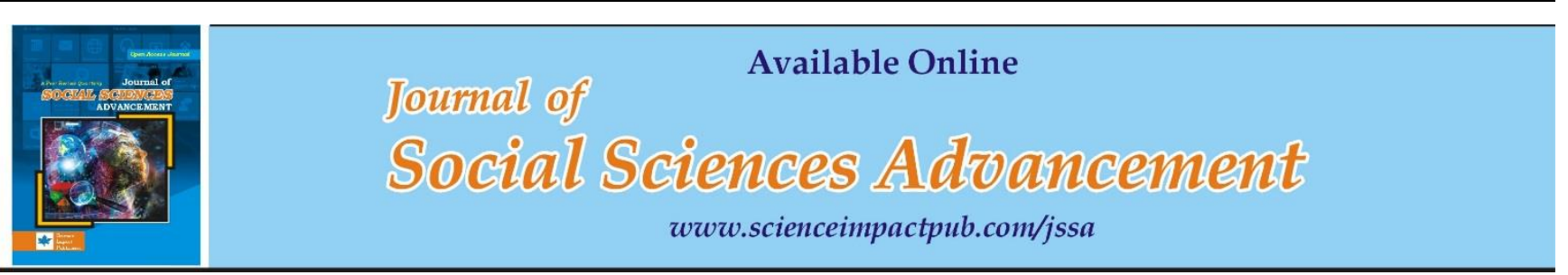

\title{
PERCEPTION OF SECONDARY SCHOOL TEACHERS REGARDING THE EFFECTIVENESS OF INTERACTIVE SMART-BOARD TECHNOLOGY
}

Tanveer Ahmad ${ }^{*}$, Noor Muhammad ${ }^{1}$ and Allah Bakhsh ${ }^{1}$

${ }^{1}$ Institute of Agricultural Extension, Education and Rural Development, University of Agriculture, Faisalabad, Sub-campus Toba Tek Singh, Pakistan

\begin{tabular}{l} 
ABS TRACT \\
\hline Like other countries, also in Pakistan, the interactive smart board technology is the innovation of $21^{\text {st }}$ century and is being used \\
in several schools as an advanced teaching tool. The focus of study was examined the attitudes of teacher and students towards \\
the ways using Smart-boards in teaching and learning environment. All the teachers of public schools in Punjab who using the \\
Smart-board were the population of the study. Data were collected from 100 trained teachers of District Toba Tek Singh through \\
questionnaire and analyzed in the form frequency, percentage, mean, mode, standard deviation t-test and Chi-square test \\
through Statistical Package of Social Sciences (SPSS) version 23. The results revealed from the study perceived that Interactive \\
Smart-boards was found most effective tool in the teaching and learning process. The utilization of Interactive Smart-board \\
perceived more helpful to present the contents in easier way, increase motivation level of students, reduce the workload, \\
utilization of time more efficiently and make the classroom more planned and organized. The study recommend that to make \\
effective smart-board technology need proper training program in all public schools.
\end{tabular}

Keywords: Perceptions; Interactive smart-board technology; effectiveness; educational technology; ICT

Corresponding Author: Tanveer Ahmad, Email: scholarsandhu327@gmail.com

(C) The Author(s) 2021.

\section{INTRODUCTION}

Textbooks are replacing by technologies, and through this, we can explore just about anything that we want. Among other technologies, interactive smart-board (ISB) technology is the innovation of the 21st century and is not new to the global village. This is the latest enhancement in educational technology as a tool of Information Communication Technology (ICT) (Ahmad, 2017). Like other countries in Pakistan, interactive smart board technology is being used in several schools as an advanced teaching tool. It is observed that students, specifically primary grade students prefer this technology because they believe that it makes learning more exciting and brings fun. With the help of already installed software, students consider challenging or boring subjects such as biology, chemistry, physics, and mathematics more interesting with practical lessons, through a video, using interactive smart boards (Mushtaq, 2016).

The usage of computer technology and various web resources through computers inspire the conversation between teachers and students without any distance (Bicknell, 1999). The utilization of ISB technology as an instruction in the class makes a rich learning environment in terms of the audio-visual smart classroom (Levy,2002) and enhances student's accomplishment (Thompson and Flecknoe (2003). Besides this, teachers face many challenges when using the interactive smart-board, such as training of teachers and school administrations, technical support's and students' factors (Al-Faki and Khamis, 2014). They have no previous experience in teaching with high technology, such as Interactive smart-board (ISBs) in the research district. Adding new technology such as ISB in the teaching profession, teachers need practical answers to overcome the challenge.

For this purpose, the present research study was carried out to know the teacher's perception regarding the Interactive Smart-board (ISB) Technology effectiveness. Besides this, the main focus of this study was to address the challenges faced by the teachers and their needs to integrate the Interactive Smart-board Technology more effectively.

\section{METHODOLOGY}

The design of this study was descriptive in nature and conducted in Toba Tek Singh District of Punjab Province. All the teachers of ISB installed public schools were the population of the study. Out of 176 teachers (16 male and 160 female), 100 teachers (16 male out of 16 and 84 females out of 160) were selected as purposive samples. For the 
design of a valid questionnaire, the researcher looked in detail at the information which was to be extracted from the data in the context of research questions as per guidelines suggested by (Anderson, 2005). After designing the questionnaire, the researcher carried out a pilot survey to check the reliability and validity of the research. The data was collected through e-mail and face to face by sharing the Self-developed questionnaire and analyzed in the form of frequency, percentage, weighted mean, mode, standard deviation, Chi-square, and independent t-test by using Statistical Packages for Social Sciences (SPSS) version 23.

\section{RESULTS AND DISCUSSION}

The analyzed data is presented through tables, and the trends of responses are also shown through graphical representation. The results of this research were analyzed based on the responses received from the participants through a questionnaire followed by the research objectives.

Table 1. Distribution of the respondent's gender.

\begin{tabular}{lllll}
\hline Category & Frequency & Percentage & Weighted Mean & Standard Deviation \\
\hline Male & 16 & 16.0 & & \\
Female & 84 & 84.0 & 1.84 & 0.368 \\
Total & 100 & 100.0 & & \\
\hline
\end{tabular}

Table 1 showed the distribution of the gender of the respondents; the results showed the $84.0 \%$ female and $16.0 \%$ male respondents participated in the research study. The weighted mean score of $1.84 \pm .638$ with mod 2 highlighted that majority of the respondents were female.

Table 2. Usage of ISB technology in teaching.

\begin{tabular}{lrrrr}
\hline \multicolumn{1}{c}{ Category } & Frequency & Percentage & Weighted mean & Standard Deviation \\
\hline Very frequently & 2 & 2.0 & \\
Frequently & 27 & 27.0 & 3.33 \\
Occasionally & 30 & 30.0 & 1.190 \\
Rarely & 21 & 21.0 & 17.0 & \\
Never & 17 & 3.0 & \\
Once a week & 3 & 100.0 & \\
Total & 100 & & & \\
\hline
\end{tabular}

Table 2 indicated that many of the respondents (i.e., 30\%) use ISB occasionally with a weighted mean score of $3.33 \pm$ 1.190 with mod 3 . While $27 \%$ of respondents who were using ISB frequently followed by $2 \%$ very frequent users. $17 \%$ of the respondents never used the ISB for teaching purposes.

Table 3: Shortage of time for the practice of contents to be taught using ISB.

\begin{tabular}{llllll}
\hline Categories & Frequency & Percentage & Weighted Mean & Mod & $\begin{array}{c}\text { S.D. } \\
\text { Chi-Square } \\
\text { value }\end{array}$ \\
\hline Strongly Agree & 16 & 16.0 & & & \\
value
\end{tabular}

The results revealed in Table 3 demonstrated that $55 \%$ of respondents with a weighted mean of $3.42 \pm 1.13$ agreed that there is no time or there is a shortage of time for hands-on practice of the contents to be taught. 


\section{CONTENTS PRACTICE ON ISB}

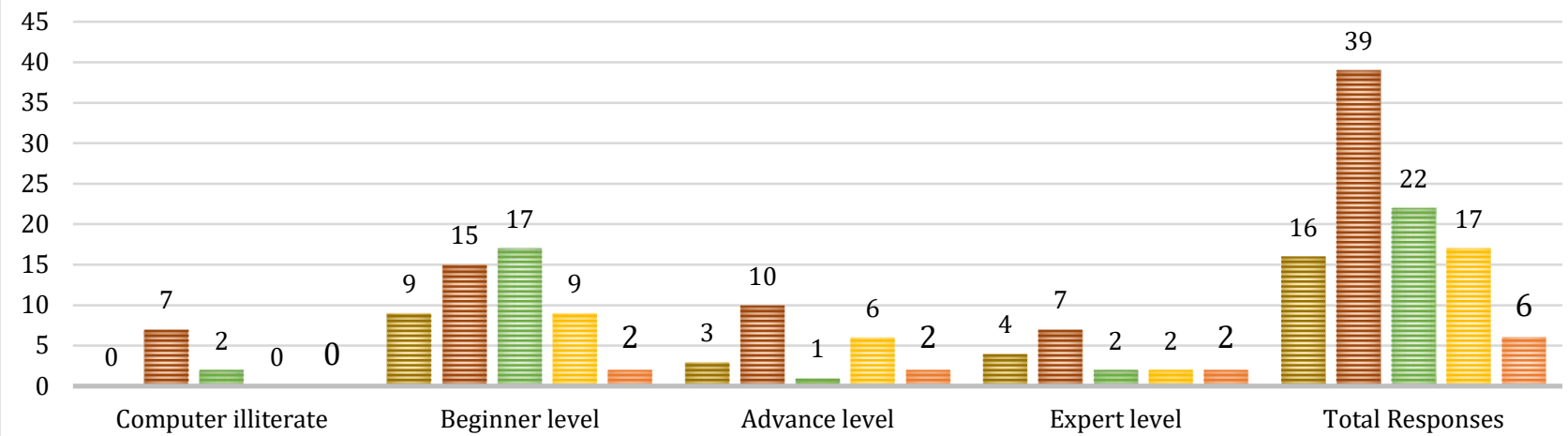

틀 Strongly Agree 를

Figure 3: Graphical illustration of shortage of time for practice

Table 4: Short time duration for the class is the hurdle

\begin{tabular}{lllcccc}
\hline Categories & Frequency & Percentage & $\begin{array}{c}\text { Weighted } \\
\text { Mean }\end{array}$ & Mod & $\begin{array}{c}\text { S.D. } \\
\begin{array}{c}\text { Chi-Square } \\
\text { value }\end{array}\end{array}$ value \\
Strongly Agree & 23 & 23.0 & & & & \\
Agree & 38 & 38.0 & 3.55 & 4 & 1.20 & 18.640 \\
Undecided & 17 & 17.0 & & & & \\
Disagree & 15 & 15.0 & & & \\
Strongly Disagree & 7 & 7.0 & & & \\
Total & 100 & 100.00 & & & & \\
\hline
\end{tabular}

Table 4 showed that $61 \%$ of respondents with a weighted mean of $3.55 \pm 1.20$ (S.D.) agreed that the short duration of the class is the main hurdle in the effective use of ISB, while only $22 \%$ disagreed with the statement.

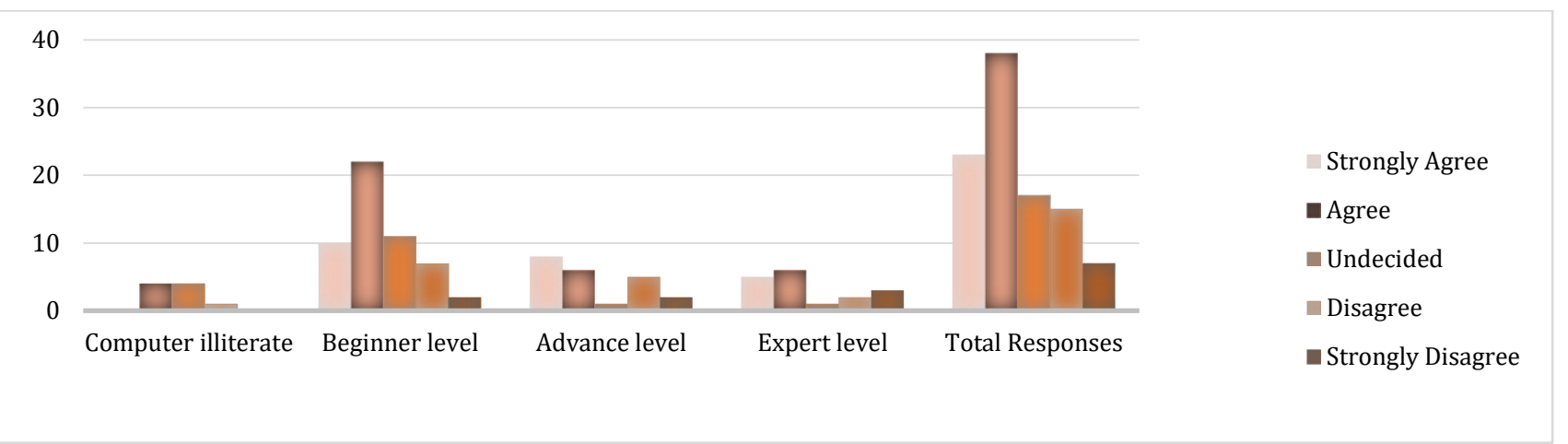

Figure 4: Graphical illustration of short time duration of the class

Table 5: Lack of computer skills.

\begin{tabular}{|c|c|c|c|c|c|c|c|}
\hline Categories & Frequency & Percentage & $\begin{array}{l}\text { Weighted } \\
\text { Mean }\end{array}$ & Mod & S.D. & $\begin{array}{l}\text { Chi-Square } \\
\text { value }\end{array}$ & P-value \\
\hline Strongly Agree & 19 & 19 & \multirow{6}{*}{3.67} & \multirow{6}{*}{4} & \multirow{6}{*}{1.04} & \multirow{6}{*}{25.682} & \multirow{6}{*}{.012} \\
\hline Agree & 49 & 49 & & & & & \\
\hline Undecided & 16 & 16 & & & & & \\
\hline Disagree & 12 & 12 & & & & & \\
\hline Strongly Disagree & 4 & 4 & & & & & \\
\hline Total & 100 & 100.00 & & & & & \\
\hline
\end{tabular}

The results of table 5 showed that more than half, $68 \%$ of respondents face the issue of computer proficiency skills and these skills are the main hurdle for the effective ISB. The P-value $(.012<0.10)$ indicated that computer skills level has a statistically significant effect on the computer competency skills for the effective use of ISB. 


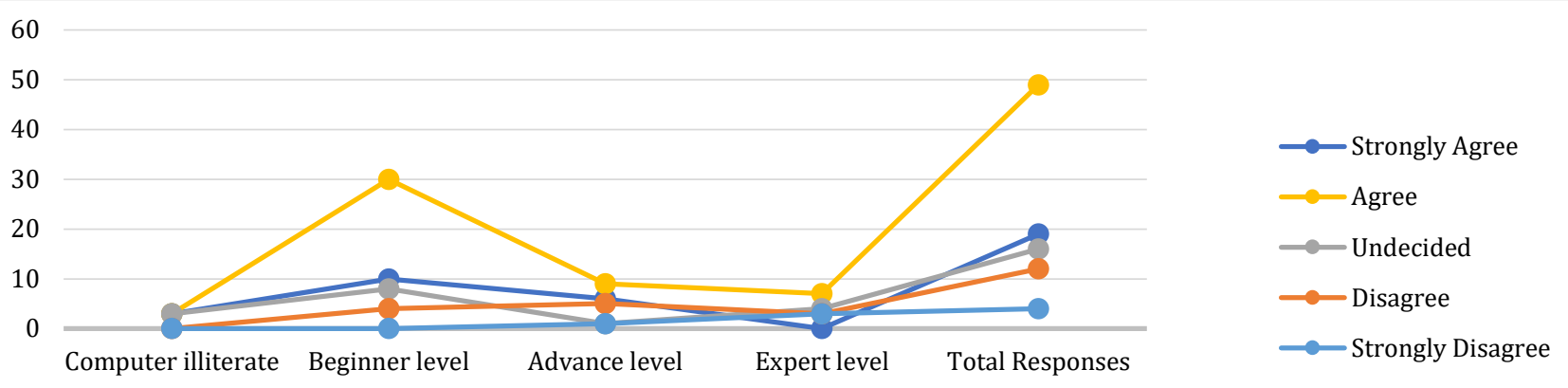

Figure 5: Graphical illustration of computer skills

Table 6. Results of Independent sample t-test.

\begin{tabular}{ccccccccccc}
$\begin{array}{c}\text { Challenges and } \\
\text { Hurdles in the } \\
\text { Effective use of } \\
\text { interactive } \\
\begin{array}{c}\text { Smartboard } \\
\text { technology }\end{array}\end{array}$ & $\begin{array}{c}\text { Equality of } \\
\text { Variances }\end{array}$ & F & Sig. & T & Df & $\begin{array}{c}\text { Sig. (2- } \\
\text { tailed) }\end{array}$ & $\begin{array}{c}\text { Mean } \\
\text { Difference }\end{array}$ & $\begin{array}{c}\text { Std. Error } \\
\text { Difference }\end{array}$ & $\begin{array}{c}90 \% \text { Confidence } \\
\text { Interval of the } \\
\text { Difference } \\
\text { Lower }\end{array}$ & Upper \\
\hline $\begin{array}{c}\text { Equal variances } \\
\text { assumed }\end{array}$ & 2.999 & 0.086 & -0.483 & 98.0 & .630 & -0.924 & 1.913 & -4.101 & 2.252 \\
\hline $\begin{array}{c}\text { Equal variances not } \\
\text { assumed }\end{array}$ & - & - & -.678 & 12.014 & 0.511 & -0.924 & 1.363 & -3.353 & 1.505 \\
\hline
\end{tabular}

Table 6 examined the challenges related to the effective use of ISB Technology in the classroom. The respondents were divided into two significant computer illiterate and computer literate categories through cut point was fixed as skills level $>=2$. Based on the tabulated value of the t-test (i.e., $\mathrm{P}=0.86<.10$ ), conclude that the computer skills level of the respondents had a significant effect on the effective use of ISB Technology in the classrooms.

Table 7: Training provided by the department regarding the effective use of ISB in the classroom.

\begin{tabular}{lllccccc}
\hline Categories & Frequency & Percentage & $\begin{array}{c}\text { Weighted } \\
\text { Mean }\end{array}$ & Mod & S.D. & $\begin{array}{c}\text { Chi-Square } \\
\text { value }\end{array}$ & P-value \\
\hline Strongly Agree & 29 & 29.0 & & & & & \\
Agree & 43 & 43.0 & & & & & \\
Undecided & 14 & 14.0 & 3.83 & 4 & 1.08 & 17.349 & .137 \\
Disagree & 10 & 10.0 & & & & & \\
Strongly Disagree & 4 & 4.0 & & & & & \\
Total & 100 & 100.00 & & & &
\end{tabular}

Table 7 demonstrated that most $72 \%$ agreed that the department does not provide sufficient training programs for the effective use of ISB Technology in the classroom.

Table 8: Department didn't offer sufficient professional programs to raise teachers' skills of using computers and ISB.

\begin{tabular}{|c|c|c|c|c|c|c|}
\hline Categories & Frequency & Percentage & Weighted Mean S. & D. & $\begin{array}{l}\text { Chi-Square } \\
\text { value }\end{array}$ & P-value \\
\hline Strongly Agree & 28 & 28.0 & \multirow{6}{*}{3.82} & \multirow{6}{*}{1.10} & \multirow{6}{*}{13.634} & \multirow{6}{*}{0.325} \\
\hline Agree & 45 & 45.0 & & & & \\
\hline Undecided & 13 & 13.0 & & & & \\
\hline Disagree & 9 & 9.0 & & & & \\
\hline Strongly Disagree & 5 & 5.0 & & & & \\
\hline Total & 100 & 100.00 & & & & \\
\hline
\end{tabular}

Table 8 presented that the majority 73\% supported the statement that the department did not offer any professional programs to enhance the skills of the teachers for the better use of computer and ISB technology. 
Table 9: School Administration does not provide periodical pedagogical support.

\begin{tabular}{llllll}
\hline Categories & Frequency & Percentage & Weighted Mean S.D. & $\begin{array}{c}\text { Chi-Square } \\
\text { value }\end{array}$ & $\begin{array}{l}\text { P- } \\
\text { value }\end{array}$ \\
\hline Strongly Agree & 19 & 19.0 & & & \\
Agree & 41 & 41.0 & & & \\
Undecided & 18 & 18.0 & 3.49 & & \\
Disagree & 14 & 14.0 & & & \\
Strongly Disagree & 8 & 8.0 & & & \\
Total & 100 & 100.00 &
\end{tabular}

The results in Table 9 exposed that the majority there were $60 \%$ respondents were considered as agreed with that the school administration does not provide pedagogical support regarding the better use of ISB Technology in the classroom activities.

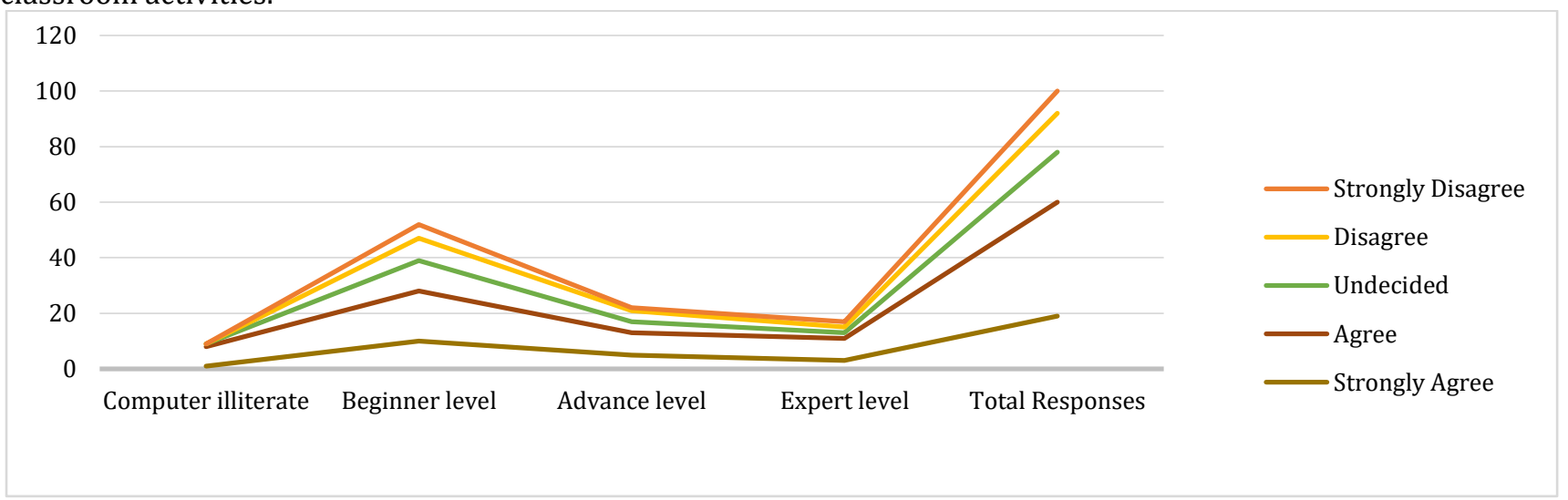

Figure 8: Graphical illustration periodical pedagogical support by administration

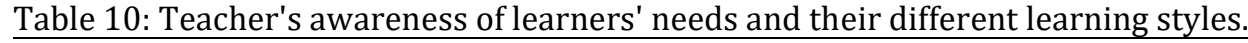

\begin{tabular}{|c|c|c|c|c|c|c|}
\hline Categories & Frequency & Percentage & Weighted Mean & S.D. & $\begin{array}{l}\text { Chi-Square } \\
\text { value }\end{array}$ & P-value \\
\hline Strongly Agree & 28 & 28.0 & \multirow{6}{*}{3.84} & \multirow{6}{*}{1.11} & \multirow{6}{*}{7.809} & \multirow{6}{*}{0.800} \\
\hline Agree & 48 & 48.0 & & & & \\
\hline Undecided & 10 & 10.0 & & & & \\
\hline Disagree & 8 & 8.0 & & & & \\
\hline Strongly Disagree & 6 & 6.0 & & & & \\
\hline Total & 100 & 100.00 & & & & \\
\hline
\end{tabular}

The results revealed in Table 10 presents that $76 \%$ of the respondents were found agreed that for the effective and better use of ISB Technology, the teachers should be aware of the needs of the students and the learning ways of the respondents.

Table 11: Teachers should read about ISB pedagogical skills.

\begin{tabular}{|c|c|c|c|c|c|c|c|}
\hline Categories & Frequency & Percentage & $\begin{array}{l}\text { Weighted } \\
\text { Mean }\end{array}$ & Mod & S.D. & $\begin{array}{l}\text { Chi-Square } \\
\text { value }\end{array}$ & $\begin{array}{l}\mathrm{P} \text { - } \\
\text { value }\end{array}$ \\
\hline Strongly Agree & 31 & 31.0 & \multirow{6}{*}{3.98} & \multirow{6}{*}{4} & \multirow{6}{*}{0.95} & \multirow{6}{*}{34.159} & \multirow{6}{*}{.001} \\
\hline Agree & 46 & 46.0 & & & & & \\
\hline Undecided & 16 & 16.0 & & & & & \\
\hline Disagree & 4 & 4.0 & & & & & \\
\hline Strongly Disagree & 3 & 3.0 & & & & & \\
\hline Total & 100 & 100.00 & & & & & \\
\hline
\end{tabular}

The results revealed in Table 11 demonstrated that $77 \%$ of teachers agreed that the teachers should acquire the pedagogical skills to use ISB Technology effectively. The P-value $(.001<0.10)$ indicated that computer skills level significantly affects the response. 
Table 12: Training programs and refresher courses should be introduced

\begin{tabular}{|c|c|c|c|c|c|c|c|}
\hline Categories & Frequency & Percentage & $\begin{array}{l}\text { Weighted } \\
\text { Mean }\end{array}$ & Mod & S.D. & $\begin{array}{l}\text { Chi-Square } \\
\text { value }\end{array}$ & $\begin{array}{l}\mathrm{P}- \\
\text { value }\end{array}$ \\
\hline Strongly Agree & 37 & 37.0 & \multirow{6}{*}{4.13} & \multirow{6}{*}{4} & \multirow{6}{*}{0.88} & \multirow{6}{*}{28.942} & \multirow{6}{*}{.004} \\
\hline Agree & 46 & 46.0 & & & & & \\
\hline Undecided & 12 & 12.0 & & & & & \\
\hline Disagree & 3 & 3.0 & & & & & \\
\hline Strongly Disagree & 2 & 2.0 & & & & & \\
\hline Total & 100 & 100.00 & & & & & \\
\hline
\end{tabular}

Table 12 indicated that a considerable number of respondents (83\%) agreed that the department should introduce the training programs and refresher courses. The P-value $(.004<0.10)$ indicated that the computer skills level has a statistically significant effect on the response.

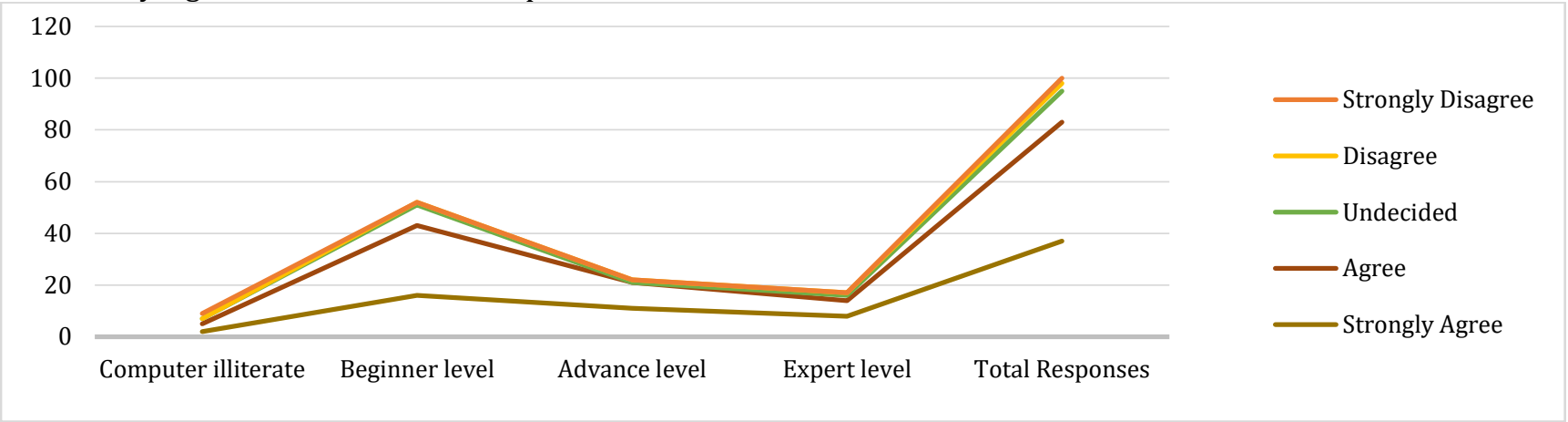

Figure 12: Graphical illustration training programs and refresher courses

Table 13: ISB increases the motivation level of the students.

\begin{tabular}{llllll}
\hline Categories & Frequency & Percentage & Weighted Mean S.D. & $\begin{array}{c}\text { Chi-Square } \\
\text { value }\end{array}$ & P-value \\
\hline Strongly Agree & 34 & 34.00 & & & \\
Agree & 46 & 46.00 & & & \\
Undecided & 13 & 13.00 & 4.03 & 21.607 & 0.042 \\
Disagree & 3 & 3.00 & & \\
Strongly Disagree & 4 & 4.00 & & \\
Total & 100 & 100.00 & & & \\
\hline
\end{tabular}

Table 13 revealed that $80 \%$ of respondents agreed that the ISB increases the motivation level of the students. The Pvalue $(.042<0.10)$ indicated that computer skills level has a statistically significant effect on the response.

Table 14: ISB increases the attention level of the students.

\begin{tabular}{|c|c|c|c|c|c|c|}
\hline Categories & Frequency & Percentage & Weighted Mean & S.D. & Chi-Square value & $\begin{array}{c}\mathrm{P}- \\
\text { value }\end{array}$ \\
\hline Strongly Agree & 39 & 39.00 & \multirow{6}{*}{4.08} & \multirow{6}{*}{0.97} & \multirow{6}{*}{18.891} & \multirow{6}{*}{0.091} \\
\hline Agree & 40 & 40.00 & & & & \\
\hline Undecided & 13 & 13.00 & & & & \\
\hline Disagree & 6 & 6.00 & & & & \\
\hline Strongly Disagree & 2 & 2.00 & & & & \\
\hline Total & 100 & 100.00 & & & & \\
\hline
\end{tabular}

Table 14 showed that $79 \%$ of respondents with a weighted mean of $4.08 \pm 0.97$ agreed that the ISB increases the students' attention level. The P-value $(.091<0.10)$ indicated that computer skills level has a statistically significant effect on the response.

Table 15 indicated that $79 \%$ of respondents with weighted mean $3.94 \pm 0.89$ agreed that the use of ISB improves the students' academic performance. 
Table 15: ISB improves the academic performance of the students.

\begin{tabular}{|c|c|c|c|c|c|c|c|}
\hline Categories & Frequency & Percentage & $\begin{array}{l}\text { Weighted } \\
\text { Mean }\end{array}$ & Mod & S.D. & $\begin{array}{l}\text { Chi-Square } \\
\text { value }\end{array}$ & $\begin{array}{l}\mathrm{P} \text { - } \\
\text { value }\end{array}$ \\
\hline Strongly Agree & 25 & 25.00 & \multirow{6}{*}{3.94} & \multirow{6}{*}{4} & \multirow{6}{*}{0.89} & \multirow{6}{*}{7.983} & \multirow{6}{*}{.786} \\
\hline Agree & 54 & 54.00 & & & & & \\
\hline Undecided & 12 & 12.00 & & & & & \\
\hline Disagree & 8 & 8.00 & & & & & \\
\hline Strongly Disagree & 1 & 1.00 & & & & & \\
\hline Total & 100 & 100.00 & & & & & \\
\hline
\end{tabular}

The results presented in table 3, 4, and 5 that there are many issues faced by the teachers for effective use of ISB; the issues are enlisted as the short time duration of the class, shortage of time to practice the contents, lack of computer competency skills and zero experience to troubleshoot the ISB. The thesis findings of the study are supported by the research of Ibrahim and Abdelmoneim (2004), along with the conclusion that the teachers who use the interactive whiteboard are confronted with challenges. The department and the management of the schools should have a clear idea about the ISB pedagogy.

Table and figure 7 revealed that the effective use of ISB in the classroom is related to computer literacy and perception of the teachers regarding the effectiveness of the ISB Technology $29 \%$ strongly agreed, $43 \%$ of the respondents agreed, $14 \%$ of the respondents disagreed and $14 \%$ of the respondents were neutral. These results also support the outcomes of the study of Colgan (2014). It was perceived that the students who learn through ISB obtain high grades with more interesting learning consistent with the study of (Yang et al., 2012). It was further found that the use of ISB technology in the classroom makes an interactive environment; the results of the study were also in line with the study of Jones et al. (2011). It was observed that IWB allows the classroom to be fully integrated with the technology. These results of the study support the finding of Betcher and Lee (2009). The teacher's approach towards the use of computers and ICT tools can be labeled as particular reactions that reflect whether they like these tools or not. These findings support the research study on perceptions of teachers by Tondeur et al. (2008). The training programs and pedagogical support are not sufficient for integrating the ISB Technology in the classroom. The stated findings of the study also support the study of Ibrahim and Abdelmoneim (2004) concluded that there is a great and immediate need for training programs and refresher courses and professional programs to raise the basic computer skills of the teachers for effective use of ISB.

Technology tools make education attractive and full of fun; they develop a positive attitude towards the subject area. These findings of the study support the study of Thompson and Flecknoe (2003). The use of ISB Technology in the classroom activities Increased the engagement, participation and attention of the students in the class. These findings of the study support the research study of (Winzenried et al., 2010). However, the present study results are also similar to other research studies (Somekh et al., 2008).

\section{CONCLUSIONS}

Based on the results and findings of the present research study and available literature, it was observed that ISBs was found the most effective tool in the teaching process. The use of ISB in the teaching process perceived as more helpful to present the contents in an easier way, reduce the workload, utilization of time more efficiently and make the classroom more planned and organized. Furthermore, the use of ISB in the learning process is perceived as more helpful to increase the motivation level, attention level, confidence level of the students. The teachers still face many challenges and hurdles regarding the effective use of ISB, including training factors and school factors.

\section{REFERENCES}

Betcher, C. and M. Lee. 2009. The interactive whiteboard revolution. Teaching with IWBs. Victoria, Australia: ACER Press.

Bicknell, J. 1999. Promoting writing and computer literacy skills through student authored Web pages. TESOL Journal, 8(1): 20-26.

Colgan, L. 2014. Making math children will love: Building positive mathitudes to improve student achievement in mathematics. What Works? Research into Practice Research Monograph 56. Student Achievement Division, Ontario Ministry of Education.

Ibrahim, M. A. and H. A. K. Abdelmoneim, 2014. Difficulties Facing Teachers in Using Interactive Whiteboards in Their Classes. American International Journal of Social Science, 3(2):136-154.

Jones, P., L. Kervin and S. McIntosh. 2011. The interactive whiteboard: Tool and/or agent of semiotic mediation. Australian Journal of Language and Literacy, 34(1): 38-60. Available online at: http://www.akea.edu.au/resources/AJU 
Levy, P. 2002. Interactive white boards in learning and teaching in two Sheffield Schools: A developmental Study. Available online at: http://www.shef.ac.Uk/erg/projects/

Somekh, B., C. Lewin. and S. Steadman. 2008. Embedding interactive whiteboards in teaching and learning: the process of change in pedagogic practice. Educational Information Technology. pp. 291-303.

Thompson, J. and M. Flecknoe. 2003. Raising attainment with an interactive whiteboard in key stage 2. Management in education. 17: 29-33.

Tondeur, J., M. Valcke and J. V. Braak. 2008. A multidimensional approach to determinants of computer use in primary education: teacher and school characteristics. Journal of Computer Assisted Learning, 24(6): 494-506.

Winzenried, A., B. Dalgarno and J. Tinkler. 2010. The interactive whiteboard: A transitional technology supporting diverse teaching practices. Australian Journal of Educational Technology, 26(4): 534-552. Available online at: http://www.ascilite.org.au/ajet

Yang, K. T. and T. H. Wang. 2012. Interactive whiteBoard: Effective interactive teaching strategy designs for biology teaching. Dans A. Silva, E. Pontes, A. Guelfi and S.T. Kofuji (Dir.), E-Learning - Engineering, on-job training and interactive teaching. 139-156.

Ahmad, S. 2017. Use of Educational Technology in Classrooms. Education Youth Ambassador (EYA), LAHORE. Retrived at: https://rtepakistan.org/blog/2017/01/31/use-of-educational-technology-in-classrooms/

Mushtaq, M. (2016, September 5). Teachers reluctant to use interactive smart boards. Dawn, Kharachi Edition: https://www.dawn.com/news/1282187

Al-Faki, I. M., \& Khamis, A. H. A. (2014). Difficulties facing teachers in using interactive whiteboards in their classes. American International Journal of Social Science, 3(2), 136-158.

Publisher's note: Science Impact Publishers remain neutral with regard to jurisdictional claims in published maps and institutional affiliations.

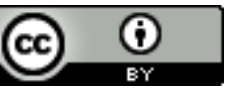

Open Access This article is licensed under a Creative Commons Attribution 4.0 International License, which permits use, sharing, adaptation, distribution and reproduction in any medium or format, as long as you give appropriate credit to the original author(s) and the source, provide a link to the Creative Commons license and indicate if changes were made. The images or other third-party material in this article are included in the article's Creative Commons license, unless indicated otherwise in a credit line to the material. If material is not included in the article's Creative Commons license and your intended use is not permitted by statutory regulation or exceeds the permitted use, you will need to obtain permission directly from the copyright holder. To view a copy of this license, visit https://creativecommons.org/licenses/by/4.0/.

(C) The Author(s) 2021 